International Journal of Electrical Engineering and Technology (IJEET)

Volume 12, Issue 9, September 2021, pp. 76-90, Article ID: IJEET_12_09_008

Available online at https://iaeme.com/Home/issue/IJEET? Volume $=12 \&$ Issue $=9$

ISSN Print: 0976-6545 and ISSN Online: 0976-6553

DOI: https://doi.org/10.34218/IJEET.12.9.2021.008

(C) IAEME Publication

Scopus Indexed

\title{
HYBRIDZATION OF SOLAR WIND RENEWABLE POWER SYSTEMS USING MODELING AND SIMULATION
}

\author{
Prashant Gautam $^{1}$, Jaya Shukla ${ }^{2}$, Dr. Rajnish Bhasker ${ }^{2}$, Satyam Kumar Upadhaya ${ }^{2}$ \\ ${ }^{1}$ M.Tech, Electrical Engineering, Department of Electrical Engineering, \\ UNS Institute of Engineering and Technology, Veer Bahadur Singh Purvanchal University, \\ Jaunpur, Uttar Pradesh, India \\ ${ }^{2}$ Assistant Professor, Department of Electrical Engineering, UNS Institute of Engineering and \\ Technology, Veer Bahadur Singh Purvanchal University, Jaunpur, Uttar Pradesh, India
}

\begin{abstract}
The modeling, simulation and control strategy of a hybrid power system (HPS) integrating a wind energy conversion system(WECS) and a solar photovoltaic system $(S P V)$. The model includes wind turbine, photovoltaic panels, permanent magnet synchronous generator (PMSG), power converters and maximum power point tracking (MPPT) controllers. A supervisory control unit, designed to execute maximum power point tracking (MPPT), is introduced to maximize the simultaneous energy harvesting from overall power generation under different climatic conditions. Two contingencies are considered and categorized according to the power generation from each energy source, and the load requirement. In PV system Perturb \& Observe $(P \& O)$ algorithm is used as control logic for the Maximum Power Point Tracking (MPPT) controller and Hill Climb Search (HCS) algorithm is used as MPPT control logic for the Wind power system in order to maximizing the power generated. The dynamic behavior of the proposed HPS is examined under different conditions based on wind speed variation and solar radiations. The developed HPS consists of a $50 \mathrm{~W}$ photovoltaic panel and 300 $W$ wind turbine. The resultant model offers a good strategy to ensure power reliability under all conditions using renewable energies. A Simulinkmodel of the proposed Hybrid system with the MPPT controlled Boost converters and Voltage regulated Inverter for stand-alone application is developed in MATLAB.
\end{abstract}

Key words: wind, power, solar, photovoltaic, reliability, Boost converters, Voltage regulate

Cite this Article: Prashant Gautam, Jaya Shukla, Rajnish Bhasker, Satyam Kumar Upadhaya. Hybridzation of Solar Wind Renewable Power Systems Using Modeling and Simulation. International Journal of Electrical Engineering and Technology (IJEET). 12(9), 2021, pp. 76-90.

https://iaeme.com/Home/issue/IJEET?Volume $=12 \&$ Issue $=9$ 


\section{INTRODUCTION}

Renewable energy sources (RES) such as Solar, Wind, Geothermal, Tidal, Hydro etc. are inexhaustible by nature. The REShave been found promising towards building sustainable and ecofriendly power generation. Due to the limitation of conventionalresources of fossil fuels, it has compelled the evolution of hybrid power system. Therefore, new ways to balance the load demand is by integrating RES into the system. Hybrid system enables the incorporation of renewable energy sources and transferals the dependency on fossil fuels, while sustaining the balance between supply and demand. The significant characteristic of hybrid power system includes, system reliability, operational efficiency.

The hybrid power system enables to overcome the limitations in wind and photovoltaic resources since their performance characteristics depends upon the unfavorable changes in environmental conditions. It is probable to endorse that hybrid stand- alone electricity generation systems are usually more reliable and less costly than systems that depend on a single source of energy. On other hand one environmental condition can make one type of RES more profitable than other. For example, Photovoltaic (PV) system is ideal for locations having more solar illumination levels and Wind power system is ideal for locations having better wind flow conditions. Moreover, both wind and solar systems are non-linear systems with a maximum point called maximum power point (MPP). To reach this MPP, a maximum power point tracking (MPPT) controller should be applied. Many techniques were proposed and published in the literature. For RES especially the variable speed wind energy conversion systems, Permanent Magnet.

Synchronous generator (PMSG) is gaining popularity. PMSG have a loss free rotor, and the power losses are confined to the stator winding and stator core. A multi-pole PMSG connected to power converter can be used as direct driven PMSG in locations with low wind speed there by eliminating the gearbox which adds weight, losses, cost and maintenance. A gearless construction of wind conversion system represents an efficient and reliable wind power conversion system. In a PV system, a solar cell alone can produce power of 1 to 2 watt. The solar cell is modeled by two diodemodel.

The solar cells are connected in series and parallel to form a PV panel or module. The PV modules are connected in series and parallel to form a PV array in order to generate appropriate amount of power.

These techniques include but not limited to increment conductance, constant voltage method, constant current method,

curve-fitting, steepest descent, perturb and observe (P\&O), fuzzy logic (FL), artificial neural network (ANN). The selection between these methods is based on the cost, the complexity, the accuracy, the convergence speed and the applicability [4]. The method used in this paper for the solar power is the $\mathrm{P} \& \mathrm{O}$ technique which is one of the most used MPPT algorithms, because of its easy implementation. For the wind energy system, Tip Speed Ratio (TSR) control method is adopted because of its good performance with fast response and high efficiency.

Thus a PV system consisting of PV array, Maximum Power Point Tracking (MPPT) boost converters, and Wind power system consisting of wind turbine, PMSG, rectifier and MPPT boost converter is integrated into Solar Wind hybrid power system (SWHPS). The efficiency and reliability of the SWHPS mainly depends upon the control strategy of the MPPT boost converter. The solar and wind power generation cannot operate at Maximum power point (MPP) without proper control logic in the MPPT boost converter. If the MPP is not tracked by the controller the power losses will occur in the system and in spite of wind and solar power availability, the output voltage of the hybrid system will not boost up to the required value. The 
output voltage of the PV and Wind power generation are quite low as compared with the desired operating level. So, this outputvoltage is brought to desired operating value of $220 \mathrm{~V}$ using Boost converter with MPPT controller at each source.

The control logic of the MPPT controlled boost converter for the Wind power generation and PV based generation are selected on the basis of ease of implementation and robustness of the Hill Climb Search (HCS) and Perturb \& Observe (P\&O) algorithm respectively. To ensure power reliability, many scientists recommend to not using one intermittent power source such as solar or wind but suggest the integration of both of them working either together or alternatively. That was named hybrid power system. Many investigations have been conducted in hybrid power system. M.Natsheh and A. Albarbar proposed a hybrid power system based on wind and solar energy. S. Kumar and V. K. Garg presented a hybrid solar-wind system with storage fuel cell in India. C. Marisarla and K. R. Kumar introduced a hybrid wind and solar energy system with battery storage for an isolated system. However, these solutions can't fully ensure continuous power supply since the wind speed and sunshine are unpredictable and the battery energy can sometimes be insufficient.

This work proposes a hybrid power system which consists in the integration of three renewable energy sources composed ofwind, solar and biodiesel energies as well as a storage battery in order to increase the power stability and reliability. Finally, the simulations results are presented and discussed. This deals with the simulation and control of (PV/wind) hybrid systems. Study of modeling and simulation on the entire PV/wind/battery hybrid system is carried out under MATLAB/Simulinkenvironment.

\section{MATERIALS METHODS}

\subsection{Hybrid Power System}

The proposed hybrid power system consists of PY panels, wind turbine, dc-dc converters and DC load. The schematic representation of the system is shown in Fig. 1 and the electrical rated powers of all components used in this study are as follow: the wind turbine is $300 \mathrm{~W}$, the solar panel is $50 \mathrm{~W}$ and the DC load is $300 \mathrm{~W}$.

\subsubsection{Solar Photovoltaic System}

\section{Modeling and Design of PV Module}

Solar module is composed of several cells mounted in series and/or in parallels. When mounted in series, the total voltageis the sum of every cell voltage and the current keeps the same. On contrary, when mounted in parallels, the current is the sum of every cell current and the voltage keeps the same. Our solar module includes 36 cells mounted in series.

The considered equivalent circuit of solar cell is depicted in Fig. 2. It consists of photocurrent, diode, shunt resistor and series resistor. The used mathematical model of the solar cell is based on the photovoltaic current equation as follow

$$
I_{p V}=I_{p h}-I_{s}\left(\exp \frac{q\left(V+R_{s} I\right)}{A K T}-1\right)-\frac{V+R_{s} I}{R_{s h}}
$$

Where, $I_{\mathrm{ph}}$ is the photonic current, $\mathrm{I}_{\mathrm{s}}$ is the saturation current dependent on cell temperature, $\mathrm{q}$ is the electric charge $\left(1.6 \times 10^{-19}\right.$ Coulombs), $\mathrm{K}$ is Boltzmann's constant $\left(1.38 \times 10^{-23} \mathrm{~J} / \mathrm{K}\right), \mathrm{T}$ is the cell's absolute temperature, $A$ is the idealizing factor, $R_{s}$ is the series resistance, $R_{\text {sh }}$ is the shunt resistance, $\mathrm{V}$ is the cell output voltage. The photocurrent Iphmainly depends on solar 
radiation and cell temperature described in the following equation. Furthermore $I_{s}$ is the cell's reverse saturation currentspecified as below

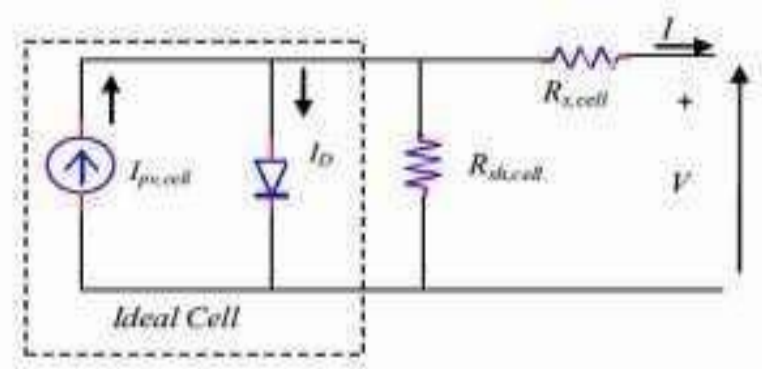

Figure 1 Equivalent circuit of an ideal and practicalPV cell.

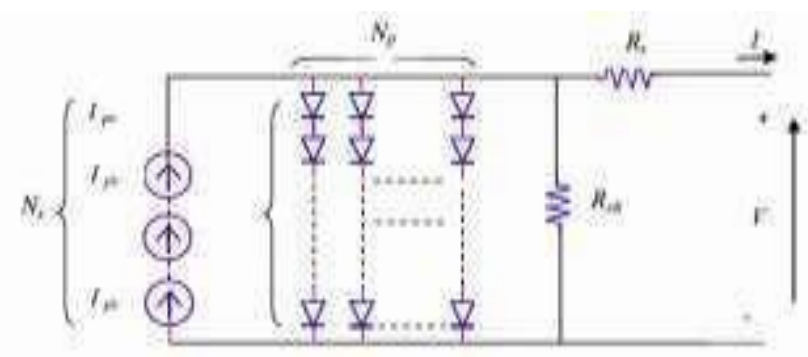

Figure 3 Equivalent circuit of PV module.

$$
I_{p h}=\left(I_{s c}+K_{i}(T-298)\right) \frac{G}{1000}
$$

Where, $I_{\mathrm{se}}$ is the short-circuit current, $\mathrm{K}$ is the current coefficient temperature, $\mathrm{G}$ is the current irradiance in $\left(\mathrm{W} / \mathrm{m}^{2}\right)$ and 1000 is the irradiance at standard operating conditions.

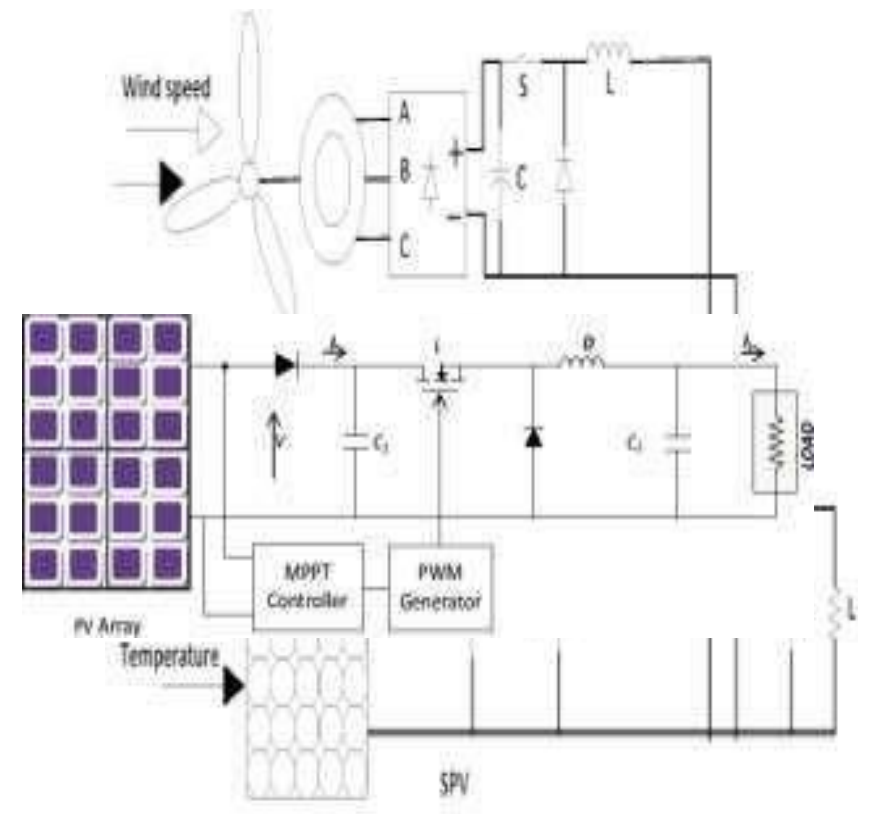

Figure 4 Proposed hybrid power system 


$$
I_{s}=\frac{I_{s c}+K_{i} \Delta T}{\exp \left(\frac{V_{o c}+K_{V} \Delta T}{A V_{t}}\right)-1}
$$

Where, $V_{o c}$ is the voltage open circuit, $\mathrm{K}_{\mathrm{v}}$ is the voltage coefficient temperature, $\Delta \mathrm{T}$ is the temperature at standard operating conditions and $\mathrm{V}_{\mathrm{t}}=\mathrm{NKT} / \mathrm{q}$ where $\mathrm{N}$ is cells number.

\section{Solar Photo voltaic Control System}

The proposed PV model is PWX500 and its specifications are shown in table 1. The PY system isa non-linear system with a MPP. In order to maintainthe system working at the MPP, a boost converter is inserted between the PY and the load. The P\&Oalgorithm is adopted to tune the duty cycle of the boost converter to keep the PY system at the maximum point. The working principle of this algorithm is that a slight perturbation is introduced tothe system which changes the module power. If the power increases due to the perturbation, then the perturbation is continued in that direction. After the peak power is reached, the power at the next instant decreases and hence after that the perturbation reverses. When the steady state is reached, the algorithm oscillates around the peak point. The $\mathrm{P} \& \mathrm{O}$ algorithm flow chart is shown in Fig. 3 and the adopted SPV system in Fig. 4.

The power flow of the dc-dc converter is controlled by varying the on/off duty cycle of the converter.The average output voltage is determined by the equation

$$
\frac{V_{\text {out }}}{V_{\text {in }}}=\frac{1}{1-D}
$$

Where, $D$ is the duty cycle, $V_{\text {out }}$ is the dc-dc converteroutput voltage and $V_{\text {in }}\left(V_{\text {in }}=V_{p v}\right)$ is the input voltage.The SPV system was simulated with a variable solarirradiance and the results are presented below. Fig. 5-adisplayed the solar irradiance profile and in Fig. 5-b and Fig. 5-c, it is shown that the PV output power andthe voltage V';np respectively vary according to theirradiance profile. Between 4 and 6 seconds, the SPVoperates at its rated output power which is around $50 \mathrm{Watt} 1000 \mathrm{~W} / \mathrm{m}^{2}$

Fig. 6 clearly demonstrates that the SPY output power oscillates around its maximum power for each irradiance. The irradiances applied are $200 \mathrm{~W} / \mathrm{m}^{2}, 400 \mathrm{~W} / \mathrm{m}^{2}, 600 \mathrm{~W} / \mathrm{m}^{2}, 800 \mathrm{~W} / \mathrm{m}^{2}$ and $1000 \mathrm{~W} / \mathrm{m}^{2}$. The oscillation is illustrated by a cloud of points around the MPP respectively. The peak is reached at $1000 \mathrm{~W} / \mathrm{m}^{2}$ with power oscillation around $50 \mathrm{~W}$.

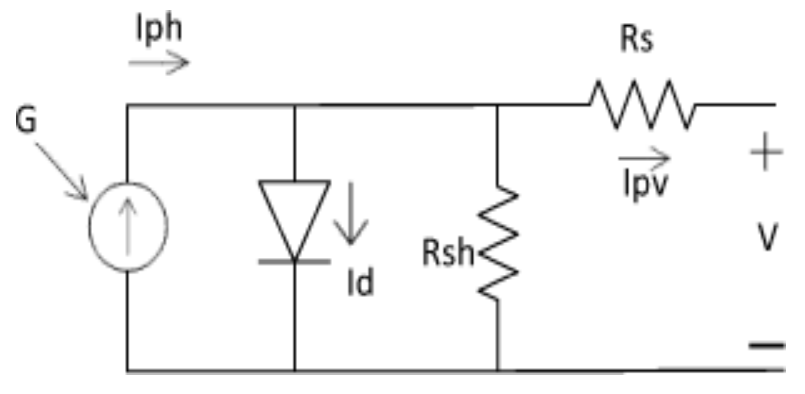

Figure 5 Solar cell equivalent circuit 
Hybridzation of Solar Wind Renewable Power Systems Using Modeling and Simulation

Table 1 Solar Panel Characteristics

\begin{tabular}{|l|c|}
\hline Parameters & Values \\
\hline Solar panel power $\operatorname{Pmp}(\mathrm{W})$ & 50 \\
\hline Current at maximum power $\operatorname{Imp}(\mathrm{A})$ & 2.9 \\
\hline Voltage at maximum power $\operatorname{Vmp}(\mathrm{V})$ & 17.2 \\
\hline Short-circuit current $\operatorname{Isc}(\mathrm{A})$ & 3.2 \\
\hline Open circuit voltage $\operatorname{Voc}(\mathrm{V})$ & 21.6 \\
\hline Nominal cell temperature $\operatorname{Noct}\left({ }^{\circ} \mathrm{C}\right)$ & 25 \\
\hline Temperature coefficient of $\operatorname{Isc}\left(K_{i}\left({ }^{\circ} \mathrm{K}\right)\right)$ & $1.46 \times 10^{-3}$ \\
\hline Temperature coefficient of $\operatorname{Voc}\left(K_{v}\left({ }^{\circ} \mathrm{K}\right)\right)$ & $-79 \times 10^{-3}$ \\
\hline Cells number $N s$ & 36 \\
\hline
\end{tabular}

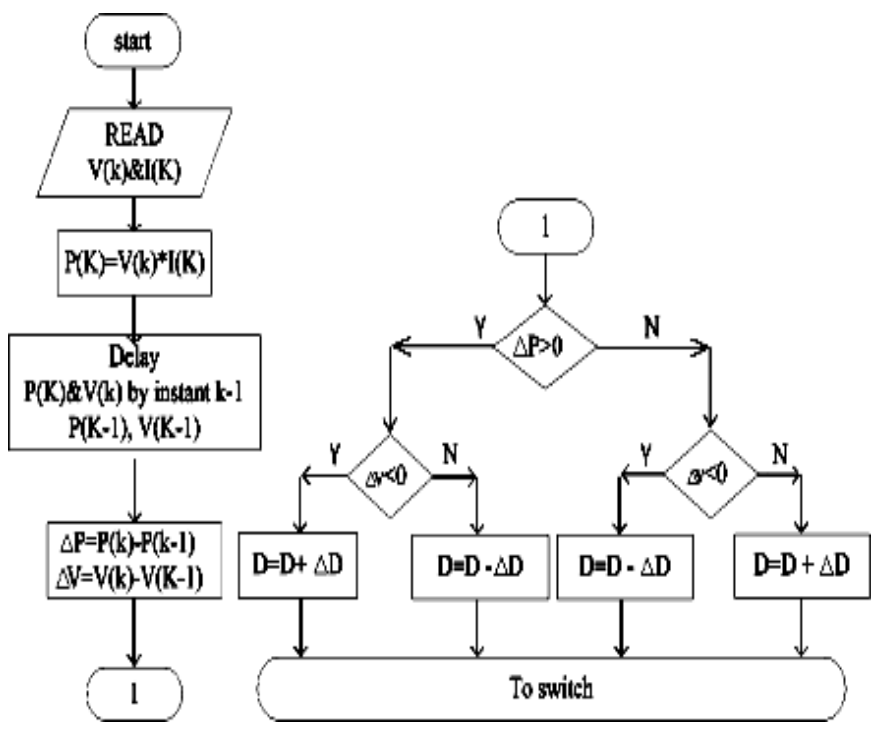

Figure 6 Perturb and observe algorithmflow chart

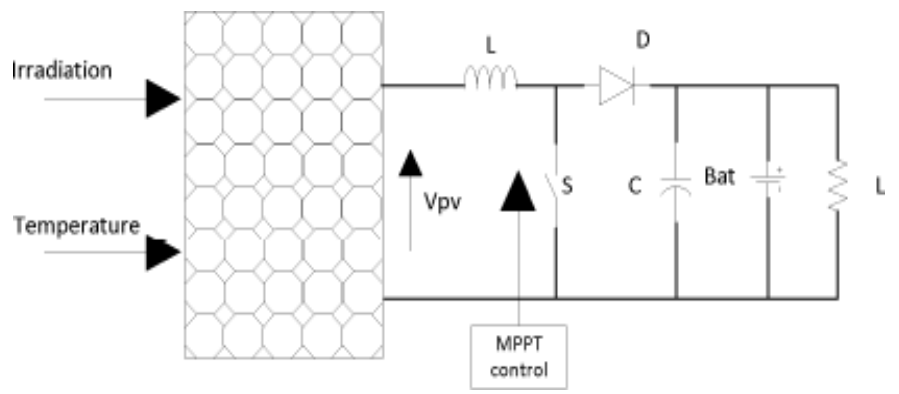

Figure 7 Solar photovoltaic power system 


\subsection{Wind Energy Conversion System}

\subsubsection{Modeling and Design of WECS}

The wind energy conversion system is presented in Fig. 7 and the wind turbine characteristics in Table.

The WECS converts the wind kinetic energy into electrical energy. The actual mechanical powerprovided by wind turbine is given by the equation:

$$
P_{w}=\frac{1}{2} \rho C_{p}(\lambda, \beta) A V^{3}
$$

Where, $\mathrm{p}$ is the air density, $\mathrm{A}$ is the swept area of therotor blade, it is equal to $\pi \mathrm{R}^{2}, \mathrm{v}$ is the wind speed, and $C_{p}(\lambda, \beta)$ is the power coefficient. The power coefficient determines the efficiency of the wind turbine depending on the Tip Speed Ratio $\lambda$ and the pitch angle $(\beta)$. A. stands for the ratio between turbine speed and the wind speed. It is given by the equation

$$
\lambda=\frac{\omega R}{V}
$$

Where, $\omega$ is the turbine angular speed, $R$ is the turbine blade radius. $C_{p}(\lambda, \beta)$ depends on the wind turbine characteristics.

$$
C_{p}(\lambda, \beta)=0.5176\left(\frac{116}{\lambda}-0.4 \beta-5\right) e^{\frac{21}{\lambda}}+0.0068 \lambda
$$

Where,

$$
\frac{1}{\lambda}=\frac{1}{\lambda+0.08 \beta}-\frac{0.035}{1+\beta^{3}}
$$

Theoretically, the wind turbine maximum power coefficient is 0.593 which is called the limit of Betz, but the practical range is between 0.2 and 0.4 .

\subsubsection{WECS Control System}

The wind turbine is a non-linear system; therefore it doesnot always work in optimal condition. In order to keep it working at maximum condition, a MPPT controller is used. The tip speed ratio (TSR) technique is adopted.The process to get the maximum power of the wind turbine goes as follow.
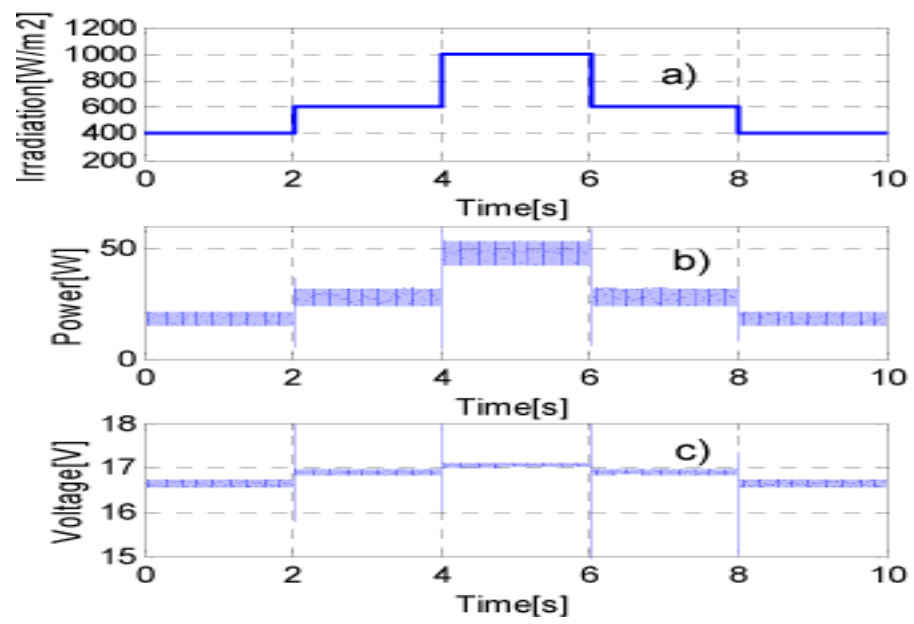

Figure 8 SPV with variable irradiance:

(a)solar irradiance profile, (b)output power, c) reference voltage 
Hybridzation of Solar Wind Renewable Power Systems Using Modeling and Simulation

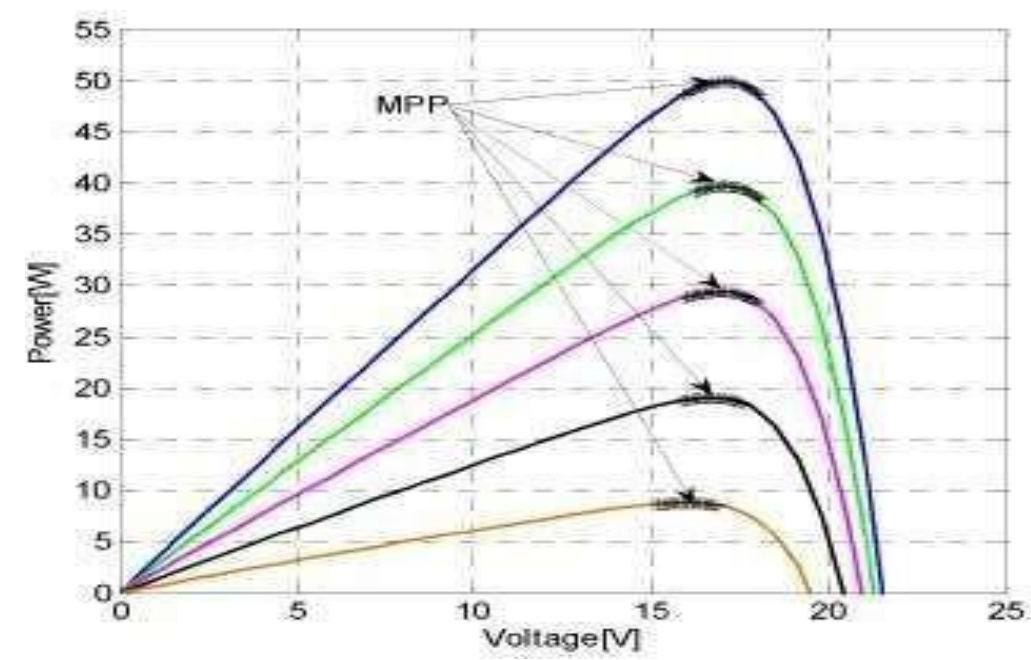

Figure 9 Maximum power points with irradiance variation

The optimum power of the wind turbine is given by the following equation considering the optimal tip speed ratio $\left(\lambda^{\mathrm{opt}}\right)$ and $\beta=0$.

$$
P_{\text {eol }}^{o p t}=\frac{1}{2} \rho C_{p}\left(\lambda^{o p t}\right) A V^{3}
$$

Taking into account the WECS efficiency $\eta$, the output optimum power is calculated as below

$$
P_{\text {out }}^{\text {opt }}=U_{\text {out }} I_{\text {out }}^{\text {ref }}=\eta P_{\text {eol }}^{\text {opt }}
$$

Where, $\mathrm{I}^{\text {ref }}$ is the output reference current. From equation (10), the reference current is obtained by

$$
I_{\text {out }}^{\text {ref }}=\frac{\eta P_{\text {eol }}^{\text {opt }}}{U_{\text {out }}}
$$

To maximize the output power, we need to control the output current that is the inductor current forwhich voltage is given by

$$
U_{L}(t)=L \frac{d I}{d t}
$$

From this equation, we obtain the output current equation

$$
I_{\text {out }}(p)=\frac{1}{L \cdot p} U_{L}
$$

A PI controller is used to regulate this output current.The regulation method is illustrated in the Fig. 9.

To get the PI controller parameters, the following closed-looptransfer function was used.

$$
G(p)=\left(K_{p}+\frac{K_{i}}{p}\right) \frac{1}{L \cdot p}=\frac{K_{i}}{L} \frac{p T_{i}+1}{P^{2}}
$$

The WECS output power is analyzed with an input variable wind speed. In Fig. 9-b, we observe that the output power varies according to the wind speed profile displayed in Fig. 9-a. 
In addition, Fig.10 proves that the output current follow the input reference current in order to extract the maximum power from the wind turbine.

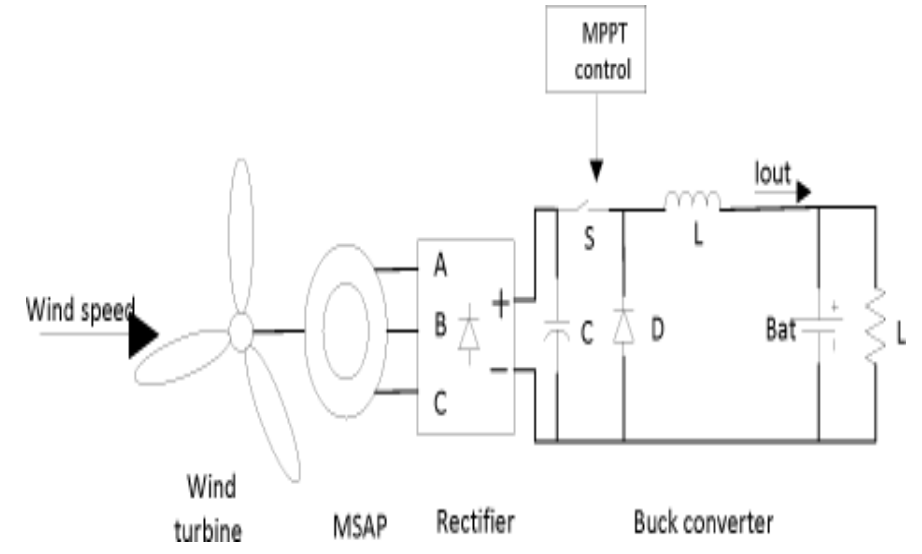

Figure 10 Wind energy conversion system

Table 2 Wind Turbine Characteristics

\begin{tabular}{|l|c|}
\hline Parameters & Values \\
\hline Rotor diameter $(\mathrm{m})$ & 2.2 \\
\hline Number of blades & 3 \\
\hline Rated output power $(\mathrm{W})$ & 300 \\
\hline Power max output $(\mathrm{W})$ & 450 \\
\hline Speed wind minimal start $(\mathrm{m} / \mathrm{s})$ & 3 \\
\hline Rated wind speed $(\mathrm{m} / \mathrm{s})$ & 8 \\
\hline Speed wind operation $(\mathrm{m} / \mathrm{s})$ & $3 \sim 25$ \\
\hline Security wind speed $(\mathrm{m} / \mathrm{s})$ & 40 \\
\hline
\end{tabular}

\subsection{Energy Sources Coupling and Control Strategy}

The WECS and SPV work simultaneously as primary Hill Climb Search MPPT algorithm for wind turbineThe HCS algorithm for MPPT control logic sources. In normal conditions, the WECS and theSPV provide the power to the load.

The block diagram of PV-wind hybrid power system is shown in Fig. 8. The hybrid generations consist of Photovoltaic based generation and Wind Power Generation. A comprehensive mathematical analysis of the Hybrid generation will be discussed in this section.

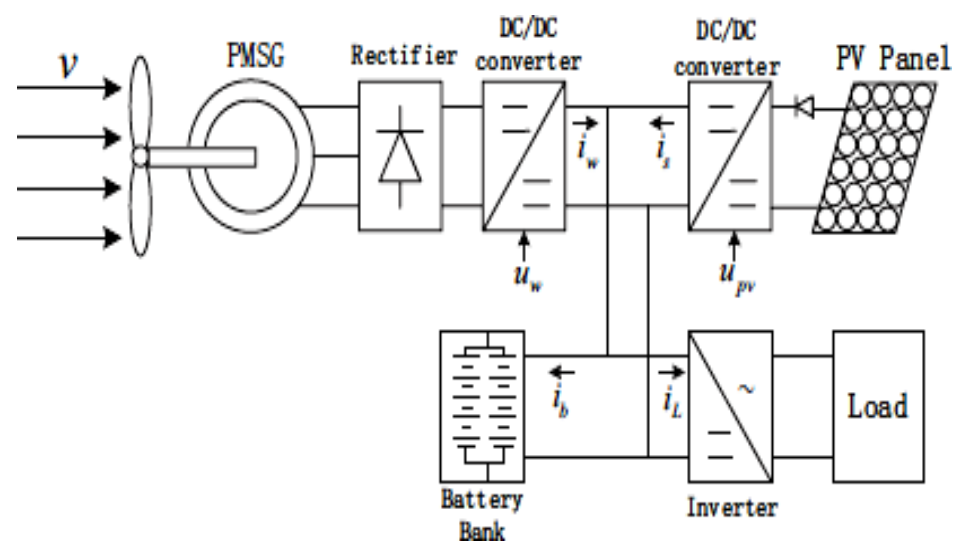

Figure 11 Block diagram of PV-Wind hybrid system 


\section{Perturb and Observe MPPT Algorithm for PV array}

Perturb and Observe (known as P\&O) algorithm, shown in Fig .9, is used in this paper for maximum power tracking of PV array. This method involves perturbation of the voltage, $\mathrm{V}$, and observing the change in power output, P. If the perturbation in one direction increases the power output of the PV array, then the same direction of perturbation is continued. Otherwise, the direction of perturbation is reversed. Thus, it is a continuous process of searching for the voltage on power $\mathrm{V}_{\mathrm{s}}$ voltage $(\mathrm{P}-\mathrm{V})$ curve, which increases the power output of the PV array. Thismethod is well described in the literature.

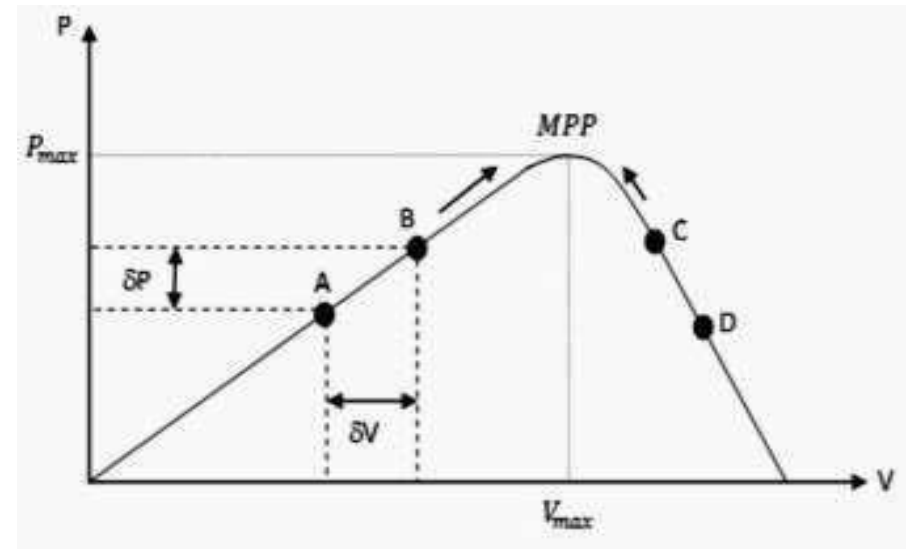

Figure 12 Description of $\mathrm{P} \& \mathrm{O}$ algorithm for MPPT

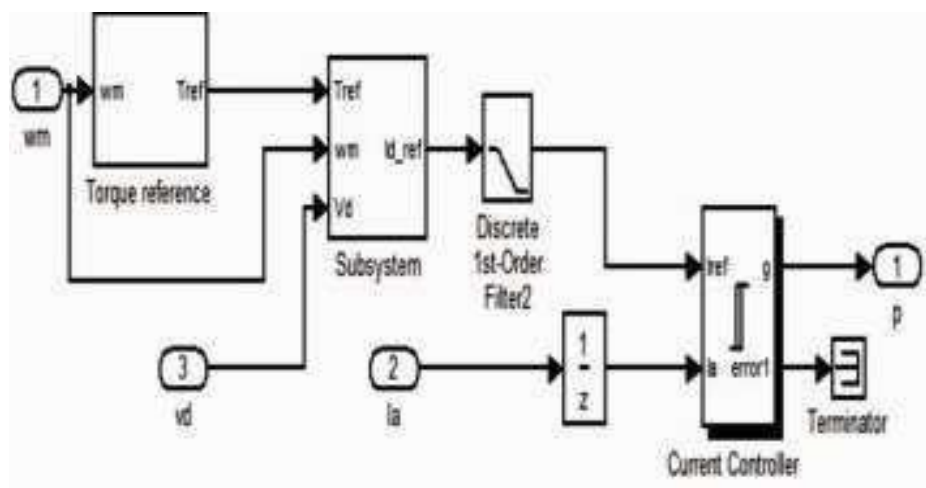

Figure 13 Sub-system implementation of MPPT control for Wind Power system

The inputs to the controller are voltage, current and speed of PMSG. Using the speed and voltage samples the reference current is calculated. It iscompared with the current measured and the erroris utilized to compute the duty cycle of the power electronic switch in boost converter which controls the operation of wind power generation at MPPT.

\section{Voltage Regulated Inverter Design}

The inverter plays a key role in the hybrid power generation. The load voltage, frequency is controlled and maintained constant using inverter in stand-alone operation. The proposed voltageregulated inverter maintains the output voltage and frequency constant irrespective of change in wind speed, solar irradiation levels and load condition. The rectified and boosted DC voltage from the PV, wind is applied as input to the inverter. The schematic diagram of Voltage regulated inverter is shown in Fig. 11. 


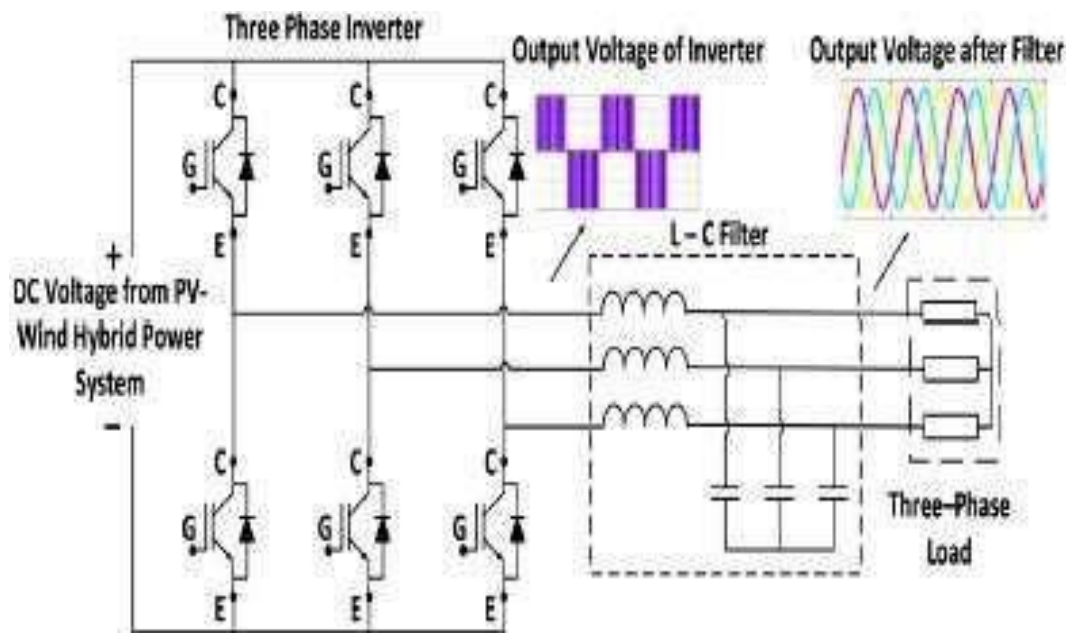

Figure 14 Voltage Regulated inverter

\section{HPS SIMULATION RESULTS AND DISCUSSION}

The hybrid power system is simulated and analyzed according to two scenarios. The simulation is done within 20 seconds interval. Recall that the PV panel is $50 \mathrm{~W}$, the wind turbine is 300 $\mathrm{W}$, and the rated load power consumption is $300 \mathrm{~W}$. The WECS works during the first 4 seconds and stops working the rest of time and the SPVworks for 5 seconds and stops working. The simulations results are presented and analyzed in this section.

Fig. 14-a and Fig. 14-b show the WECS output powerand the SPV output power respectively.

The hybrid wind and solar output power is higher thanthe load power demand. As a result, the hybrid power system supplies power to the load to the load during the complete simulation time despite the variation of the wind and solar power.
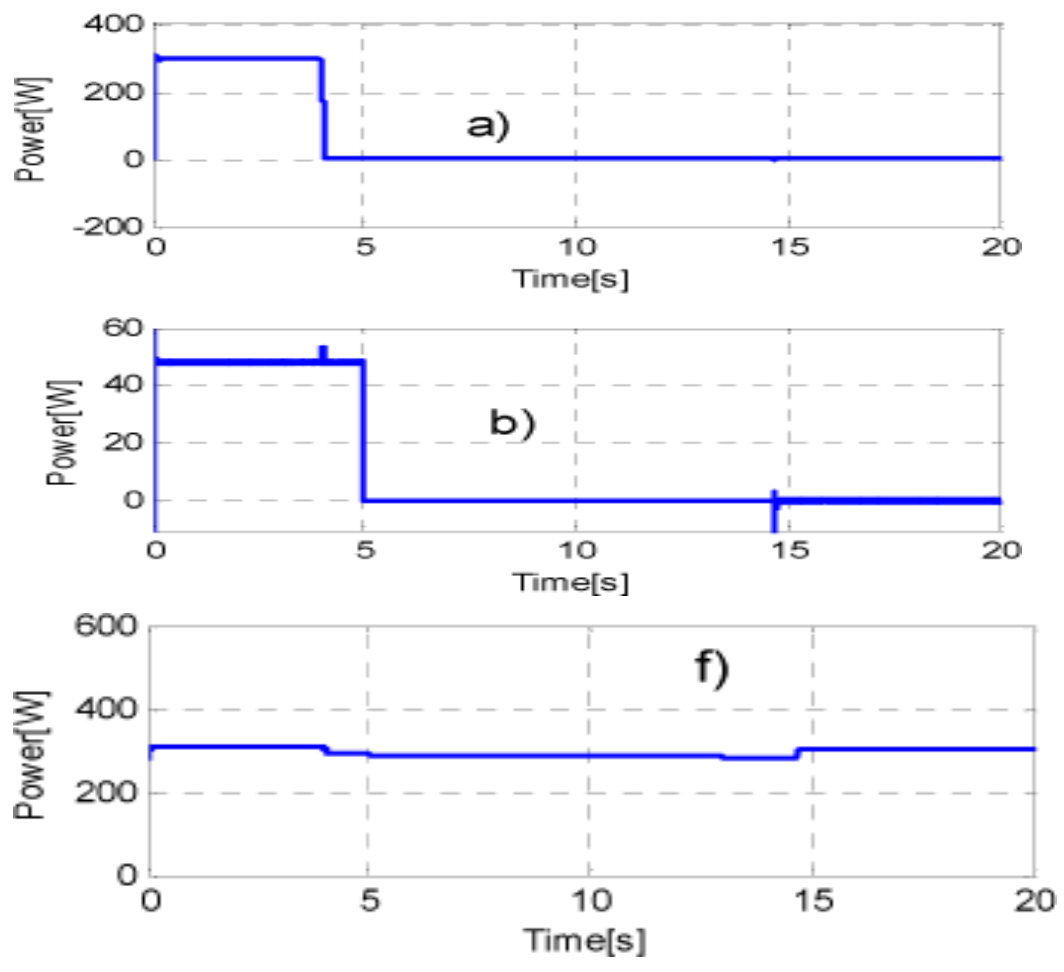

Figure 15 System response during the first case:

(a)WECS power, (b)SPV power (c) load power 
Hybridzation of Solar Wind Renewable Power Systems Using Modeling and Simulation
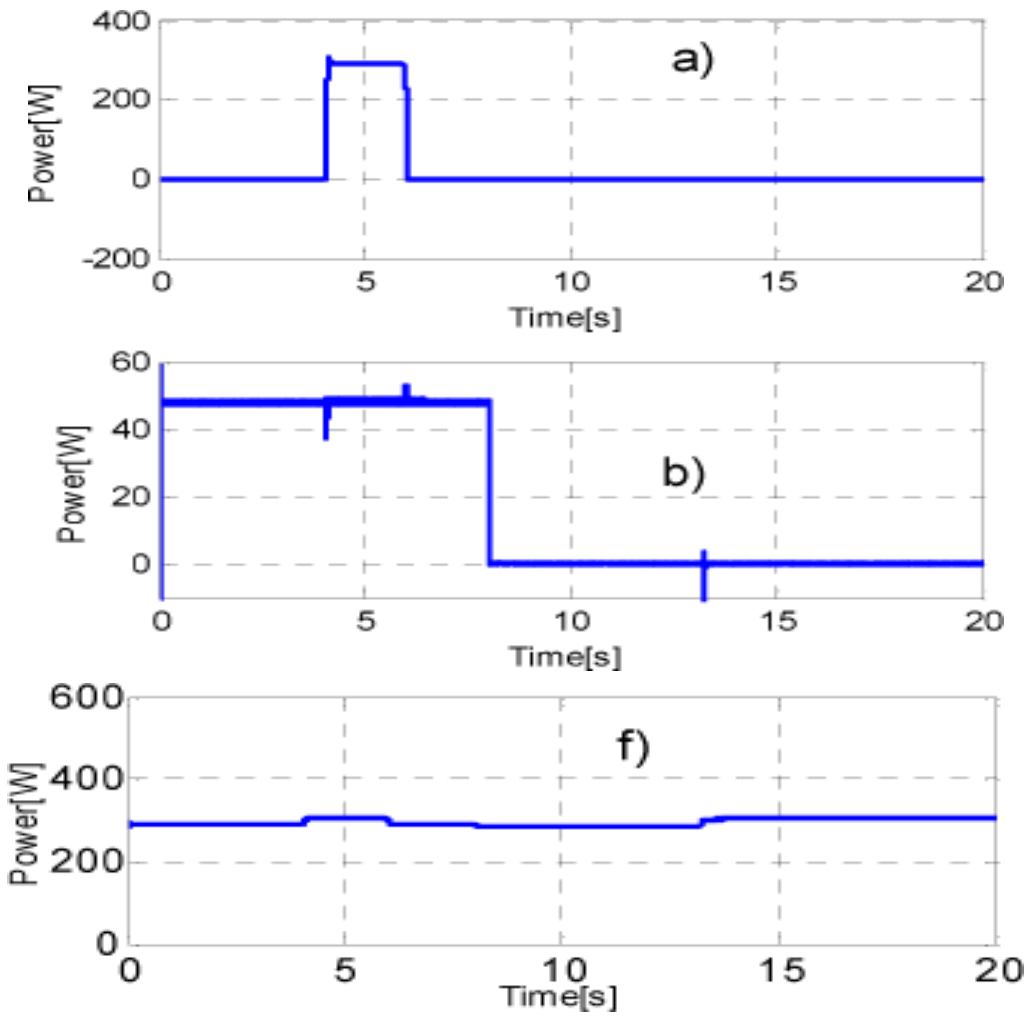

Figure 16 System response during thesecond case,

(a) WECS power, SPY power, (c) load power

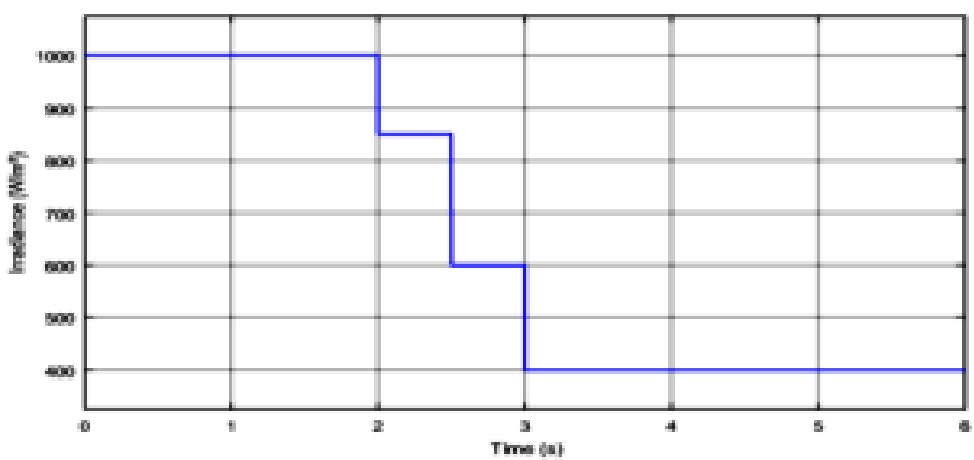

Figure 17. PV changing irradiation level

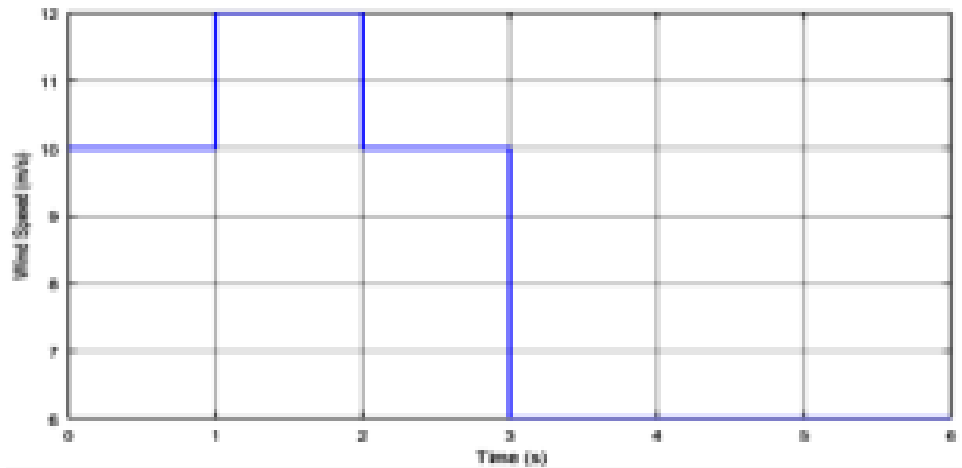

Figure 18 Wind speed changinglevel 


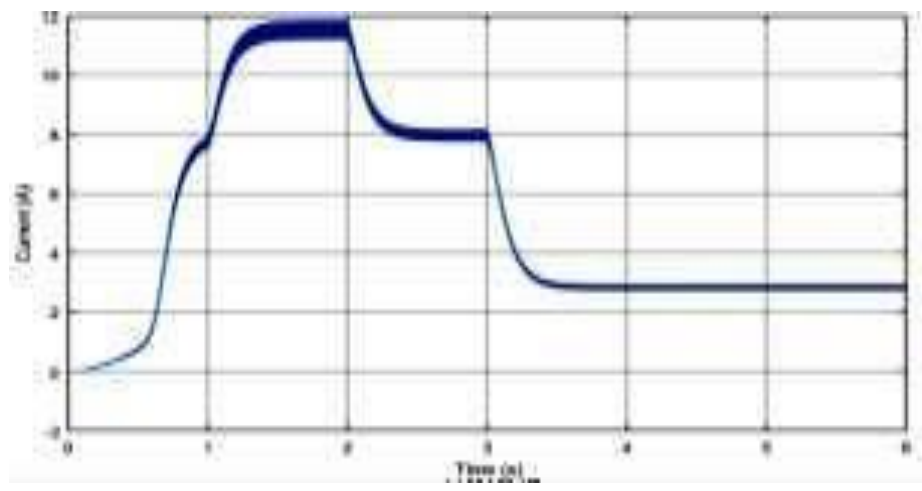

Figure 19 Output current wind

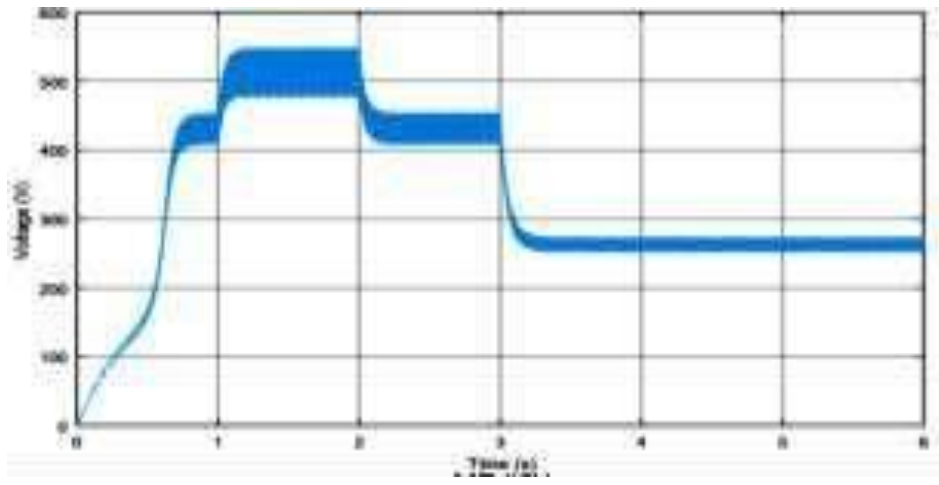

Figure 20. Output Voltage wind

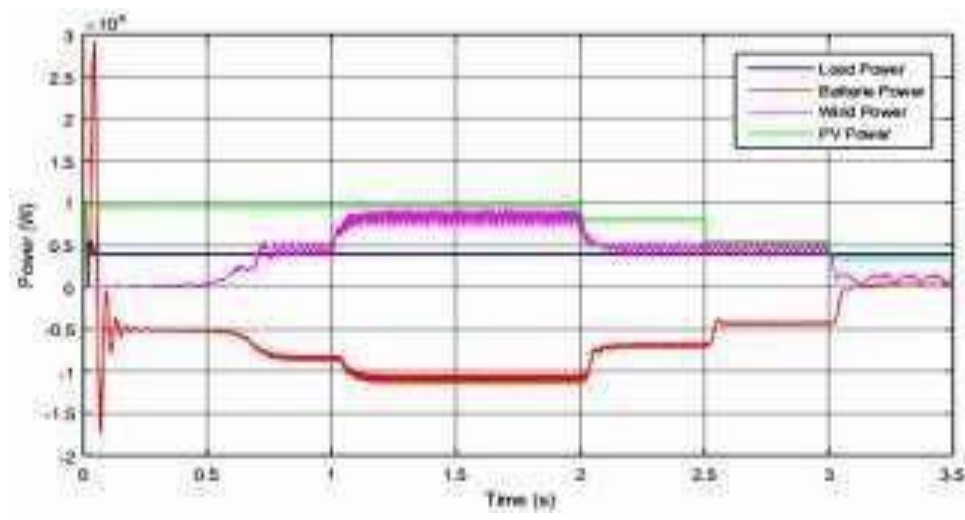

Figure 21 Power generation of the hybrid system undervarying wind speed and irradiation

\section{CONCLUSION}

The PV power generation branch characteristics are analyzed. Fig. 18 shows the voltage with MPPT controller under different irradiances. It verifies that the PV power generation branch can readily perform the MPPT and achieve the maximum output power at a given irradiance; fig 20, 21 shows the output current and voltage for the PMSG wind system with HCS algorithm MPPT controller.

It can be clearly observed that the MPPT controller plays a key role in the hybrid power system. In order to reduce the lossesand to improve the efficiency and performance of the hybrid system a faster MPPT controller is required. In the first case with PI voltage regulated inverter the output voltage is unstable with disturbance in frequency compared to the FLC voltage regulated inverter shows in fig 23 and fig 25 . The power flow in the second case provide the power efficiency and the advantage of fuzzy logic controller algorithm to control the inverter and the stability of system compared to the PI voltage regulated inverter. 
Nature has provided ample opportunities to mankind to make best use of its resources and still maintain its beauty. In this context, the proposed hybrid PV-wind system provides an elegant integration of the wind turbine and solar PV to extract optimum energy from the two sources. It yields a compact converter system, while incurring reduced cost.

A hybrid power system integrating three renewable energy sources composed of wind and solar has been studied in this work. The proposed method includes $\mathrm{P} \& \mathrm{O}$ algorithm to achieve the solar panels maximum power extraction and TSR technique to obtain the maximum power from the wind turbine. The model shows that the load is always sufficiently supplied with power despite the variation of the wind speed and the solar irradiance. This hybrid system was analyzed through two scenarios based on the variation of the wind speed and the solar irradiance.

\section{REFERENCES}

[1] H. Seftdgar and S. A. Gholamian, "Fuzzy logic control of wind turbine system connection to PM synchronous generatorfor maximum power point tracking," Int. J. Intelligent Syst. and Appl, vol. 07, 2014

[2] S. Singh, L. Mathew, and S.L. Shimi, "Design and simulation of intelligent control MPPT technique for PV module using MATLAB/SIMSCAPE," Int. J. of Adv. Res. in Elect, Electro. and lnstr. Eng., vol. 2, pp. 2278-8875, 2013.

[3] N. A. Kamarzaman and C. W. Tan, "A comprehensive review of maximum power point tracking algorithms for photovoltaic systems," Renewable and Sustainable Energy Reviews, vol. 37, pp. 585-598, 2014.

[4] A. Anurag, S. Bal, S. Sourav, and M. Nanda, "A comprehensible review of maximum power point tracking techniques for photovoltaic systems," Int. J. of sustainable energy, vol. 35, pp. 478-50 I, 2016.

[5] M.-F. Tsai, c.-S. Tseng, and Y.-H. Hung, "A novel MPPT control design for wind-turbine generation systems using neural network compensator," IECON 2012-38th Annual Conf on IEEE Indust. Elect. Soc., pp. 3521- 3526,2012.

[6] M. A. Abdullah, A. H. M. Yatim, and C. Wei Tan, "A study of maximum power point tracking algorithms for wind energy system," IEEE First Conf. on Clean Energy and Tech. CET, pp. 321-326, 2011.

[7] Y. Xia, K. H. Ahmed, and B. W. Williams, "A new maximum power point tracking technique for penmanent magnet synchronous generator-based wind energy conversion system," IEEE Trans. on power electronics, vol. 26, p. 3609-3620, 2011.

[8] Natsheh, E.M.; Albarbar, A.; Yazdani, J., "Modeling and control for smart grid integration of solar/wind energy conversion system," 2nd IEEE PES International Conference and Exhibition on Innovative Smart Grid Technologies (ISGT Europe), pp.1-8, 5-7 Dec. 2011.

[9] Bagen; Billinton, R., "Evaluation of Different Operating Strategies in Small Stand-Alone Power Systems," IEEETransactions on Energy Conversion, vol.20, no.3, pp. 654-660, Sept. 2005

[10] S. M. Shaahid and M. A. Elhadidy, "Opportunities for utilization of stand-alone hybrid (photovoltaic + diesel+ battery) power systems in hot climates," Renewable Energy, vol. 28, no. 11, pp. 1741-1753, 2003.

[11] Goel, P.K.; Singh, B.; Murthy, S.S.; Kishore, N., "Autonomous hybrid system using PMSGs for hydro and wind powergeneration," 35th Annual Conference of IEEE Industrial Electronics, 2009. IECON '09, pp.255,260, 3-5 Nov. 2009.

[12] Foster, R., M. Ghassemi, and A. Cota, Solar energy: renewable energy and the environment. 2010, Boca Raton: CRC Press. 
[13] Salam, Z.; Ishaque, K.; Taheri, H., "An improved two-diode photovoltaic (PV) model for PV system," 2010 Joint International Conference on Power Electronics, Drives and Energy Systems (PEDES) \& 2010 Power India, pp.1,5, 20-23 Dec. 2010.

[14] Yuncong Jiang; Qahouq, J.A.A.; Orabi, M., "AC PV solar system distributed architecture with maximum power pointtracking," IEEE 34th International Telecommunications Energy Conference (INTELEC), pp.1-5, Sept. 30 2012-Oct. 42012.

[15] Paul C.-P. Chao, Wei-Dar Chen, Chih-Kuo Chang. Maximum power tracking of a generic photovoltaic system via a fuzzy controller and a two-stage DC-DC converter. 30September 2011 / Accepted: 23 April 2012/ Published online: 9 May 2012

[16] Villalva MG, Gazoli JR. Comprehensive approach to modeling and simulation of photovoltaic arrays. IEEE TransPower Electron 2009; 24:1198-208.

[17] Faranda, R. and Leva, S. (2008) Energy Comparison of MPPT Techniques for PV Systems. WSEAS Transactions onPower Systems, 3, 447-455.

[18] Zainal Salam, Jubaer Ahmed, Benny S. Merugu "The application of soft computing methods for MPPT of PV system:A technological and status review "ELSEVIER Applied Energy 107 (2013) 135-148

[19] Nur Atharah Kamarzamana, Chee Wei Tan, "A comprehensive review of maximum power point tracking algorithms for photovoltaic systems," Renewable and Sustainable Energy Reviews, vol.37, pp- 585-598, Sep 2014

[20] Ridha BENADU', Brahim KHIARI', Anis SELLAMI "Predictive Current Control Strategy for a Three-Phase Grid Connected Photovoltaic Wind Hybrid System" 978-1-4673-97681/16/\$31.00 @2016 IEEE

[21] Dong-Min Miao; Jian-Xin Shen, "Comparative study on permanent magnet synchronous generator systems with various power conversion topologies," 2013. Fourth International Conference on Power Engineering, Energy and Electrical Drives (POWERENG), pp.17381743, 13-17, May 2013.

[22] Salam, Z.; Ishaque, K.; Taheri, H., "An improved two-diode photovoltaic (PV) model for PV system," 2010 Joint International Conference on Power Electronics, Drives and Energy Systems (PEDES) \& 2010 Power India, pp.1,5, 20-23 Dec. 2010. 